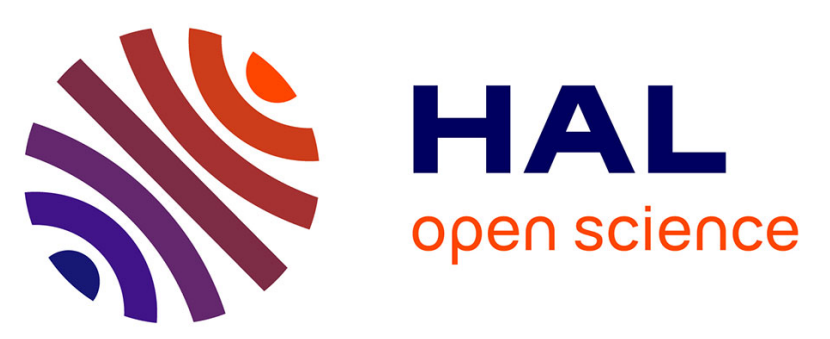

\title{
In vitro comet and micronucleus assays do not predict morphological transforming effects of silica particles in Syrian Hamster Embryo cells
}

\author{
Christian Darne, Catherine Coulais, Francine Terzetti, Caroline Fontana, \\ Stéphane Binet, Laurent Gaté, Yves Guichard
}

\section{To cite this version:}

Christian Darne, Catherine Coulais, Francine Terzetti, Caroline Fontana, Stéphane Binet, et al.. In vitro comet and micronucleus assays do not predict morphological transforming effects of silica particles in Syrian Hamster Embryo cells. Mutation Research - Genetic Toxicology and Environmental Mutagenesis, 2016, 796, pp.23-33. 10.1016/j.mrgentox.2015.11.012 . hal-01264612

\section{HAL Id: hal-01264612 \\ https://hal.science/hal-01264612}

Submitted on 29 Jan 2016

HAL is a multi-disciplinary open access archive for the deposit and dissemination of scientific research documents, whether they are published or not. The documents may come from teaching and research institutions in France or abroad, or from public or private research centers.
L'archive ouverte pluridisciplinaire HAL, est destinée au dépôt et à la diffusion de documents scientifiques de niveau recherche, publiés ou non, émanant des établissements d'enseignement et de recherche français ou étrangers, des laboratoires publics ou privés. 
In vitro comet and micronucleus assays do not predict morphological transforming effects of silica particles in Syrian Hamster Embryo cells.

Christian Darne*, Catherine Coulais, Francine Terzetti, Caroline Fontana, Stéphane Binet, Laurent Gaté, Yves Guichard

Département Toxicologie et Biométrologie, Institut National de Recherche et de Sécurité (INRS),

Rue du Morvan, CS 60027

54519 VANDOEUVRE LES NANCY Cedex, France.

* Correspondence should be addressed to: christian.darne@inrs.fr 


\section{ABSTRACT}

Crystalline silica particles and asbestos have both been classified as carcinogenic by the International Agency for Research on Cancer (IARC). However, because of the limited data available, amorphous silica was not classifiable.

In vitro, the carcinogenic potential of natural crystalline and amorphous silica particles has been revealed by the Syrian Hamster Embryo (SHE) cell transformation assay. On the other hand, the genotoxic potential of those substances has not been investigated in SHE cells. And yet, genotoxicity assays are commonly used for hazard evaluation and they are often used as in vitro assays of reference to predict a possible carcinogenic potential. The main objective of this study was to compare the genotoxic potential and the carcinogenic potential of different crystalline and amorphous silica particles in SHE cells. Three silica samples of different crystallinity were used: natural amorphous silica, partially crystallized silica and quartz silica particles. Their genotoxicity were tested through the in vitro micronucleus assay and the comet assay in SHE, and their carcinogenic potential through the SHE transformation assay. In addition, silica samples were also tested with the same genotoxicity assays in V79 hamsterlung cells, a common in vitro model for particle exposure.

Results obtained in the micronucleus and the comet assays show that none of the silica was capable of inducing genotoxic effects in SHE cells and only the amorphous silica induced genotoxic effects in V79 cells. However in the SHE cell transformation assays, the partially crystallized and quartz silica were able to induce morphological cell transformation. Together, these data suggest that, in vitro, the short-term genotoxic assays alone are not sufficient to predict the hazard and the carcinogenic potential of this type of particles; SHE transformation assay appears a more reliable tool for this purpose and should be included in the "in vitro battery assays” for hazard assessment. 
Key Words: silica, genotoxicity, SHE cell transformation, in vitro micronucleus assay, in vitro comet assay, asbestos. 


\section{1 - INTRODUCTION}

Occupational exposure to some forms of silica is associated with silicosis and other respiratory pathologies. The International Agency for Research on Cancer [1] has classified quartz and cristobalite as carcinogenic to humans (Group 1) on the basis of sufficient evidence for carcinogenic effects in experimental animals and in humans. Because of the limited epidemiological and experimental data available, amorphous diatomaceous earth silica has not been classifiable for its carcinogenicity (Group 3).

The mechanisms of silica-induced carcinogenesis remain only partially understood, even if the IARC classification was based mainly on the crystallinity. Dimension, crystallinity, solubility and biopersistence are all parameters that could influence the toxicity of silica [2]. Another parameter thought to be involved is the production of reactive oxygen or nitrogen species (ROS, RNS) [1], [3] and [4].

Several in vitro studies on genotoxic effects have focused on quartz particles [5] and [6] but little data is available regarding the effects of natural amorphous silica such as diatomaceous earth. In previous studies [2] and [7], crystalline silica was found to be cytotoxic and it also induced morphological transformation of Syrian hamster embryo (SHE) cells, which further acquired tumorigenic properties, whereas amorphous silica did not.

The assessment of silica hazard and of their carcinogenic potential is often based on long-term in vivo studies as for other chemicals. But in order to limit animal use, analyses are now often conducted with in vitro tests. Generally, these assays look at the cytotoxicity, the mutagenicity, the inflammatory response and the genotoxicity [8], [9] and [10]. Few studies use the in vitro cell transformation assays (CTA) for determine this carcinogenic potential, whereas these assays are useful to evaluate all carcinogens (genotoxic and non genotoxic) as demonstrated by the OECD detail review paper [11]. For the SHE CTA, more than 200 chemicals have been tested and meta-analysis of the results show a sensitivity of $92 \%$, a 
specificity of $66 \%$, a positive predictivity of $88 \%$, a negative predictivity of $75 \%$ and a concordance of $85 \%$. The SHE CTA is a useful alternative to animal experimentation for the detection of carcinogenic chemicals and could be a useful in vitro predictive tool since the only carcinogenicity test accepted by authorities so far is the in vivo two-year bioassay.

A recent study, conducted by Benigni, et al. [12], has shown the benefit of the Syrian hamster embryo cells transformation assay to efficiently identify carcinogens and especially those that are nongenotoxic. Similarly, no study has determined in the same cellular model the genotoxic and transforming effects of silica particles.

The purpose of this work was to determine whether the capacity of natural silica materials to transform SHE cells were linked to their ability to induce micronucleus formation and DNA damage in SHE and V79 cells. By this mean, we have also looked at the benefit that the SHE CTA could present for the evaluation of silica hazard. Silica materials of different crystallinity were used to test this hypothesis: a quartz silica (Min-U-Sil 5), an amorphous diatomaceous earth (DE) and its calcination product (Chd), partially crystallized into cristobalite form as a consequence of flux calcinations. Occupational exposure to these particles may occur during extraction or processing of the native material (DE, Min-U-Sil), and commercial use (Chd) in industry as a filtration agent, abrasive or adsorbent material [1]. An asbestos sample (chrysotile) with transforming potential [13] was also selected as a reference particulate sample for this study. 


\section{2 - MATERIAL AND METHODS}

\section{1 - Materials}

The materials investigated (described in Table 1) comprised: (i) an amorphous biogenic diatomaceous earth (DE), which is the source of (ii) a commercial dust, industrially prepared by flux calcination of the DE at high temperature to yield a partially crystallized cristobalite (Chd); (iii) Min-U-Sil 5 quartz, the most widely investigated silica in in vitro and in vivo studies [1]; and (iv) a chrysotile asbestos sample provided by J. Fournier (Laboratoire de Réactivité de surface, Jussieux, France), originally obtained from UICC A (International Union against Cancer, South Africa ), which was used as a positive control in the SHE cell transformation assay

\section{2 - Physicochemical characterisation of the materials}

The degree of crystallinity was determined by X-ray diffractometry (Philips diffractometer, Philips Electronics, The Netherlands). Impurities were analysed by inductively coupled plasma (ICP) spectrometry (Spectro Ciros CCD, Germany) (Table 1). Particle size distribution was measured by SEM (JEOL 840A, Japan) (Table 2).

\section{3 - Cell culture}

Syrian hamster embryo (SHE) cell cultures were established from individual 13-day gestation foetuses (inbred colony, INRS, France). All of the experiments involving animals were performed in the INRS laboratory animal facility approved by the French Ministry of Agriculture, according to the French regulations regarding the protection of animals used for experimental and other scientific purposes and the INRS ethical policy. The culture medium used was Dulbecco’s MEM (DMEM; Invitrogen, France), pH 7, supplemented with 20\% preselected fetal calf serum (Dutscher, France) and 2 mM L-glutamine (Invitrogen, France) without antibiotics. Cells were incubated at $37^{\circ} \mathrm{C}$ and $10 \% \mathrm{CO}_{2}$. Cryopreserved primary cultures were selected for cell growth, cloning efficiency, and spontaneous and induced morphological transformation. The primary and secondary cultures used in this study were from a batch that yielded results consistent with the historical laboratory data.

V79 cells (lung fibroblast from Chinese hamster, ATCC, USA, reference CCL-93) were selected for this study as they are one of the cell models recommended in OCDE guideline $\mathrm{n}^{\circ} 487$ for use in the in vitro micronucleus assay. Cells were grown in Dulbecco’s MEM (DMEM; Invitrogen, France), supplemented with 10\% fetal calf serum (Dutscher, France) and 0.5\% Penicillin/Streptomycin (5000 U-5000 $\mu \mathrm{g} / \mathrm{mL}$, Invitrogen, France). Cells were incubated at $37^{\circ} \mathrm{C}$ and $10 \% \mathrm{CO}_{2}$, as recommended by the supplier for optimal culture with our medium. 


\section{4 - Cell proliferation}

Cells (30,000 SHE cells/ml or 20,000 V79 cells $/ \mathrm{mL}$ ) were cultured for $24 \mathrm{~h}$ at $37^{\circ} \mathrm{C}$ and $10 \% \mathrm{CO}_{2}$ in culture medium. The cell cultures were then treated for $24 \mathrm{~h}$ with culture medium (control) or with particle/fibre suspensions in final concentrations between 3.3 and $13.2 \mu \mathrm{g} / \mathrm{cm}^{2}$ for the asbestos and between 20 and $80 \mu \mathrm{g} / \mathrm{cm}^{2}$ for silica. After treatment, cells were trypsinized and counted (Coulter Z1, Beckman Coulter, France). Each assay was repeated at least three times. The mean number of cells \pm SD for each treatment concentration was calculated and compared using an ANOVA-LSD test (Fisher's Least Significant Difference) (Statgraphics Centurion, Statpoint Technologies, USA).

\section{5 - SHE cloning efficiency and transformation assay.}

The assay was performed as described previously [7] and [14]. X-irradiated SHE feeder cells were seeded at $3 \times 10^{4}$ cells $/ \mathrm{ml}$ in a $60-\mathrm{mm}$ dish. After $24 \mathrm{~h}$ of incubation $\left(37^{\circ} \mathrm{C}, 10 \% \mathrm{CO}_{2}\right), 300$ SHE target cells/dish were seeded onto the feeder cells. Cells were incubated for $24 \mathrm{~h}$ at $37^{\circ} \mathrm{C}$ and $10 \% \mathrm{CO}_{2}$, and were then exposed for 7 days to at least three different concentrations: between $0.48 \mu \mathrm{g} / \mathrm{cm}^{2}$ and $1.91 \mu \mathrm{g} / \mathrm{cm}^{2}$ for asbestos and between $3.81 \mu \mathrm{g} / \mathrm{cm}^{2}$ and $30.48 \mu \mathrm{g} / \mathrm{cm}^{2}$ for silica. Control cells received culture medium alone.

After 7 days of incubation at $37^{\circ} \mathrm{C}, 10 \% \mathrm{CO}_{2}$, dishes were washed (HBSS, Invitrogen) and colonies were fixed (absolute methanol) and stained (10\% Giemsa). Colonies were counted and examined for morphological transformation with a stereomicroscope (Wild, Germany) (for photograph examples see [15]). Ten cell cultures were used per treatment concentration and control. For each treatment concentration and control in an individual assay, the following were scored: (i) total colony number; (ii) cloning efficiency (CE) = (total colony number/total target cell number seeded) $x$ 100; (iii) relative plating efficiency $(\mathrm{RPE})=(\mathrm{CE}$ of treated cells/CE of the control) x 100; (iv) number of morphologically transformed colonies; and (v) transformation frequency (TF) $=$ (the number of transformed colonies/total number of colonies) $\mathrm{x} 100$.

The mean CE of the control cultures was $23.71 \%(n=16)$. Only one spontaneous transformed colony was recorded in one of a total of 16 experiments. For each treatment concentration, data reported the pooled results from a minimum of three individual assays. TF was compared to the control using the Chi-squared test.

\section{6 - Comet assay}

Cell membrane integrity was verified just before comet experiments using the trypan blue exclusion method (data not shown). 
The Fpg-modified comet assay was used to evaluate DNA damage. This test uses the Fpg enzyme (formamido pyrimidine DNA glycoylase), a glycosylase that recognizes and cuts the modified bases, in particular at 8oxoguanine sites, producing apurinic that are converted into breaks by the associated AP-endonuclease activity. These breaks can therefore indicate oxidative DNA damage [16]. We followed the procedure of Collins et al. [17], with minor modifications. The concentrations tested ranged from 2.9 to $11.4 \mu \mathrm{g} / \mathrm{cm}^{2}$ for the asbestos and from 11.4 to $45.7 \mu \mathrm{g} / \mathrm{cm}^{2}$ for silica. Methylmethane sulfonate (MMS, Sigma-Aldrich, France) was used as a positive control at $0.125 \mathrm{mM}$.

About 20,000 cells (SHE or V79) were mixed in 1\% low-melting agarose (Sigma Aldrich, France) in complete medium at $37^{\circ} \mathrm{C}$ and transferred onto a slide pre-coated with $1 \%$ normal melting agarose (Sigma Aldrich, France). The slides were then immersed in lysis solution and kept in the dark for $1 \mathrm{~h}$ at $4^{\circ} \mathrm{C}$.

The slides were washed, drained and incubated in the dark with $50 \mu$ l of either buffer or Fpg (10 U/mL, Sigma, France) in enzyme buffer, for $30 \mathrm{~min}$ at $37^{\circ} \mathrm{C}$. The slides were then immersed in cold alkaline solution for 20 min. Electrophoresis was performed at $25 \mathrm{~V}$ and $300 \mathrm{~mA}$ for $40 \mathrm{~min}$. The slides were then washed with Tris$\mathrm{HCl}$ 0.4 M for 15 min and stained with propidium iodide.

Images of 100 randomly selected comets were analysed from each sample, using specific image analyser software (Comet assay IV, Perceptive Instruments, United Kingdom). Experiments were repeated three times. Data were expressed as the mean of the medians of the tail DNA \pm SEM, and statistical analyses were performed on the mean values using a multiple comparison method one-way ANOVA (Fisher least significant difference (LSD)) with Statgraphics Centurion software (Statpoint Technologies, USA). The $p<0.05$ level was considered to be statistically significant.

\section{7 - Micronucleus assay.}

For the micronucleus assay, $2.5 \times 10^{4}$ cells (SHE or V79) were seeded in Labtek ${ }^{\circledR}$ slides (Nunc A/S, Denmark) with $1 \mathrm{~mL}$ of culture medium. After $24 \mathrm{~h}$, they were treated with $1 \mathrm{~mL}$ of sample preparation for $24 \mathrm{~h}$. Concentrations ranged from 2.9 to $11.4 \mu \mathrm{g} / \mathrm{cm}^{2}$ for the asbestos and from 11.4 to $54.4 \mu \mathrm{g} / \mathrm{cm}^{2}$ for silica. MMS was used as a positive control at $0.25 \mathrm{mM}$. Cells were washed with PBS (phosphate buffer saline, Invitrogen, France) and fixed for 15 min in methanol. Slides were washed in PBS, drained, and then received one drop of Pro Long Gold antifade reagent ${ }^{\circledR}$ with DAPI (Molecular Probe, Invitrogen, France). About 1000 cells/point were analyzed for the presence of MN (micronucleus) and mitotic cells. Each assay was repeated three times. Statistical analysis of MN induction was performed using an ANOVA-LSD test (Fisher's Least Significant 
Difference) (Statgraphics Centurion, Statpoint Technologies, USA). The $p<0.05$ level was considered to be statistically significant. 


\section{3- RESULTS}

\section{1 - Physicochemical characterisation of the materials:}

Chemical compositions and sample impurities are presented in Table 1. Amorphous silica DE contained $1.3 \%$ iron. The heated DE (Chd) was partially crystallized (47\% cristobalite) and contained $1.9 \%$ iron by mass. The Min-U-Sil quartz (100\% crystallized) contained $0.05 \%$ iron and $0.16 \%$ aluminium.

Both DE and Min-U-Sil samples both presented homogeneous size distributions (Table 2). The Chd silica was heterogeneous, with $68.9 \%$ of particles having a diameter of less than $5 \mu \mathrm{m}$ and $31.1 \%$ with a diameter greater than $5 \mu \mathrm{m}$.

Our chrysotile sample was composed of very small fibres (96.1 \% $\mathrm{L} / \mathrm{D}>3, \mathrm{~L}<5 \mu \mathrm{m})$.

\section{2 - Cell proliferation:}

The cell proliferation data for SHE and V79 cells are presented in Figures 1A and 1B, respectively. Cells were counted 24 hours after treatment.

In SHE cells, the following concentrations yielded 50\% reductions in cell count: 8.2 $\mu \mathrm{g} / \mathrm{cm}^{2}$ for chrysotile, $65.7 \mu \mathrm{g} / \mathrm{cm}^{2}$ for Chd and $68.7 \mu \mathrm{g} / \mathrm{cm}^{2}$ for DE. At the highest Min-U-Sil concentration $\left(80 \mu \mathrm{g} / \mathrm{cm}^{2}\right)$ the cell count was $58 \%$ of the control. As expected, the asbestos was more cytotoxic than any of the silica. Min-U-Sil was the least cytotoxic silica tested. Sample toxicity can be ranked as follows: Chrysotile $>>$ Chd $\geq$ DE $>$ Min-U-Sil.

In V79 cells, a 50\% decrease in cell count was recorded at a concentration of 60.1 $\mu \mathrm{g} / \mathrm{cm}^{2}$ for silica DE. At the highest dose $\left(90.4 \mu \mathrm{g} / \mathrm{cm}^{2}\right)$ the cell counts were at $72 \%$ of the control for Chd silica and 64.6 \% for Min-U-Sil. $11.4 \mu \mathrm{g} / \mathrm{cm}^{2}$ of chrysotile gave a cell count that was $55 \%$ of the control. The sample toxicity in V79 cells can be ranked as follows: Chrysotile $>>$ DE $>>$ Min-U-Sil $>$ Chd. 


\section{3 - Relative plating efficiency (RPE) and transformation frequency (TF) of SHE cells:}

The relative plating efficiency and TF induced by the different silica and chrysotile are reported in Table 3.

The silica samples significantly reduced the RPE but the cytotoxic potency of each type of silica varied: DE > Chd> Min-U-Sil. Amorphous DE induced no morphological transformation (except for 3 colonies in one experiment at $15.24 \mu \mathrm{g} / \mathrm{cm}^{2}$ ), while a concentration-dependent increase in TF was induced by the two other silica samples. As reported previously [2] and [7], Min-U-Sil did not express any cytotoxicity in concentrations

up to $30.48 \mu \mathrm{g} / \mathrm{cm}^{2}$ but did induce morphological transformation in a dose-dependent manner. The partially crystallised Chd was slightly cytotoxic and also induced transformation in a dose-dependent manner.

The chrysotile was more cytotoxic and more transforming than silica and the effects were dose-dependent.

\section{4 - Micronuclei (MN) assessment:}

In order to detect the potential genotoxic effects of samples, induction of $\mathrm{MN}$ in the SHE and V79 cells was assessed after 24 h of treatment ( $\sim 1.3$ cell-division cycles for SHE and $~ 1.7$ cell-division cycles for V79).

After $24 \mathrm{~h}$ of treatment, none of the silica samples was able to induce an increase in MN frequency in SHE cells. Even though no significant difference was observed between the control and the highest concentrations, there was a general tendency for the number of cells with micronuclei to decrease with concentration (Figure 2A). This cannot be related to a decrease in cell division induced by the treatment because no significant change in the number of mitotic cells was observed in the assays (data not shown). The only positive sample was the asbestos, for which we observed a positive relationship between MN 
frequency and concentration. A significant response was obtained with $11.34 \mu \mathrm{g} / \mathrm{cm}^{2}$ of chrysotile.

In V79 cells (Figure 2B), the DE and chrysotile induced a significant increase in the number of micronucleated cells at the two highest concentrations and a concentrationdependent relationship is apparent. In contrast, the Chd and Min-U-Sil had no effect.

\section{5 - Comet assay:}

Cell membrane integrity, as evaluated by the trypan blue exclusion method (data not shown), was not significantly affected (over $80 \%$ survival) in either cell type after 3 or 24 hours of treatment.

The results of the comet assay are expressed as percentage of tail DNA. In the SHE cells, the mean values obtained for the positive control (methyl methanesulfonate $0.125 \mathrm{mM}$ ) were, after $3 \mathrm{~h}$ of treatment, $23.58 \% \pm 3.50$ and $62.62 \% \pm 4.71$ in the absence or presence of Fpg (which cuts DNA strands where bases are modified), respectively, and after $24 \mathrm{~h}$ of treatment, $29.51 \% \pm 9.63$ and $67.79 \% \pm 5.73$ in the absence or presence of Fpg, respectively. In V79 cells, values obtained were $15.4 \pm 2.88$ and $62.37 \pm 5.44$ after $3 \mathrm{~h}$ of MMS treatment and $20.17 \pm 1.84$ and $67.44 \% \pm 1.81$ after 24 h of treatment without or with Fpg, respectively.

Treatment of the SHE cells with chrysotile or silica samples over $3 \mathrm{~h}$ (Figures 3A and 4A) did not induce any DNA damage, as evaluated by the alkaline comet assay with or without Fpg in both cell types. Treatment with Fpg led to an increase in the tail DNA values, but without any significant difference from the control, which also presented a higher tail DNA value.

After $24 \mathrm{~h}$ of treatment (Figure 3B), a significant increase in DNA strand breaks was observed at $11.4 \mu \mathrm{g} / \mathrm{cm}^{2}$ chrysotile without Fpg treatment in SHE cells. At concentrations up 
to $45.7 \mu \mathrm{g} / \mathrm{cm}^{2}$, none of the silica samples were able to induce a significant increase in DNA strand breaks, with or without Fpg.

In V79 cells (Figure 4), only the amorphous silica DE induced a significant increase in DNA breaks at the highest concentration $\left(45.7 \mu \mathrm{g} / \mathrm{cm}^{2}\right)$ without Fpg, after $24 \mathrm{~h}$ of treatment (Figure 4B). 


\section{4 - DISCUSSION}

Crystallized silica and asbestos have both been classified as carcinogenic to humans (Group 1) by the International Agency for Research on Cancer. This classification was based on evidence obtained from both animal models and epidemiological studies [1]. Due to limited data, amorphous silica could not be classified. One of hypothesis put forward to explain the carcinogenic potential of fibres and particles is the involvement of reactive oxygen species (ROS). We have previously shown that both crystallized silica (Chd and Min-U-Sil 5) and chrysotile asbestos are able to generate ROS. The reactivity of these samples in releasing ${ }^{\bullet} \mathrm{OH}$ radicals correlated to their transforming ability, whereas amorphous silica DE was unable to generate ROS and did not show any transforming capacity [13] and [18]. Some other works have shown genotoxic effects, but no link to the carcinogenicity of these products has been made [5], [6] and [19].

The SHE cell transformation assay, which uses primary cell cultures of individual Syrian hamster embryos, is an in vitro assay that predicts carcinogenicity of chemicals using morphological transformation as an end-point. This transformation is characterised by disorganised growth patterns (criss-cross, high nuclear to cytoplasmic ratio, randomly oriented colony growth). Strong concordance has been reported between morphological changes in SHE colonies upon chemical treatment and results from carcinogenicity studies in animals [11] and [20]. This test present the advantage to be able to detect not only genotoxic carcinogens but also non-genotoxic carcinogens that often escape to in vitro tests conventionally used. As meaning, SHE CTA is very useful for hazard assessment of chemicals.

In the present work, we have shown that crystallized silica (Chd and Min-U-Sil) was able to induce transformed SHE colonies in a dose-dependent manner after seven days of 
treatment. Our results are in agreement with previous transformation studies on quartz [18], [21], [22], [23] and [24]. Hesterberg and Barrett [21] showed that two quartz samples induced a concentration-dependent increase in TF, and both of these samples were less potent than asbestos fibres. In our study, concentrations of 3.8 to $15.2 \mu \mathrm{g} / \mathrm{cm}^{2}$ induced similar TF (0.240.71\%) to that shown by Hesterberg and Barrett [21], and the crystallized silica was again found to be less potent than the asbestos $\left(0.28 \%\right.$ TF with $1.91 \mu \mathrm{g} / \mathrm{cm}^{2}$ of chrysotile vs. $0.4 \%$ TF with $30.4 \mu \mathrm{g} / \mathrm{cm}^{2}$ of Chd or $0.24 \%$ TF with $3.81 \mu \mathrm{g} / \mathrm{cm}^{2}$ of Min-U-Sil). All of these data are in agreement with the previously reported data [18].

At the same time, and in order to evaluate a possible link between transforming potential and genotoxic effects, two types of genotoxicity assays were used for the present study: the in vitro comet assay and the in vitro micronucleus (MN) assay. The genotoxicity assays are often used to determine the potential hazard of chemicals and to alert about possible consequences in terms of health impact.

Numerous studies have validated the comet assay as a sensitive method for quantifying DNA breakage and for evaluating the genotoxic potential of xenobiotics [25] and [26]. The comet assay was first used to detect the ability of chemicals to generate singlestrand and/or double-strand breaks in the DNA [27], but DNA breaks can also result from repair of some DNA lesions [28] and [29]. The comet assay can also be modified, as we made in this study, in order to allow the specific detection of damaged DNA resulting from base modification, and mainly from base oxidation, by including an enzymatic treatment step [30] and [31].

The in vitro micronucleus assay visualizes, in interphase cells, micronuclei induced by chromosome breakage events (clastogenic effects) or chromosome losses (aneugenic effects) that occur in anaphase during nuclear division [32]. The comet assay and the micronucleus assay are thus complementary tests. 
With crystalline silica, no effect was observed in the comet or in the micronucleus assay in either cell type. Our results differ from those published before where the sample concentrations used were fairly high. Indeed, Nagalakshmi et al. [10] showed that 24h treatment with Min-U-Sil followed by 18-20h treatment with cytochalasin B (CyB) induced an increase in MN frequency from concentrations of $40 \mu \mathrm{g} / \mathrm{cm}^{2}$ in V79 cells and from 160 $\mu \mathrm{g} / \mathrm{cm}^{2}$ in Hel299 cells. In a later study made by the same group, Min-U-Sil at $137.9 \mu \mathrm{g} / \mathrm{cm}^{2}$ induced a significant increase in $\mathrm{MN}$ frequency in V79 in the absence of CyB treatment but with a high cytotoxicity [6].

We chose not to use concentrations above $55 \mu \mathrm{g} / \mathrm{cm}^{2}$, firstly to avoid high cytotoxicity that could interfere with the genotoxicity assay, and secondly because concentrations below $30.4 \mu \mathrm{g} / \mathrm{cm}^{2}$ were able to induce transformed colonies in the SHE cell transformation assay. Taken together, our micronucleus results and data published before suggest that crystalline silica genotoxicity is probably discreet.

With regards to natural amorphous silica materials, these have been evaluated as nonfibrogenic and unlikely to be carcinogenic [1]. In the present work, and as expected [18], the DE was unable to induce transformed colonies (except for three colonies in one experiment). However and surprisingly, the DE silica was the only sample able to induce DNA strand breaks and micronucleus in the V79 cells. But no explanation can be given at this stage. These results show the better sensitivity of V79 cells compared to SHE cells for determining the genotoxic effects. However, as they are immortalized (derived from a spontaneous cell transformation), defective for p53, the V79 cells present altered functions that may lead to "false positive" effects compared to non-immortalized cells. Indeed, the p53 protein, which mediates the cellular response to DNA damage, is involved in cell-cycle regulation, apoptosis and DNA repair [33]. As shown by Chaung, et al. [34], the V79 p53 sequence contains two mutation points that result in a nonfunctional protein. Conversely, SHE cells are normal 
diploid cells with no alterations in the cell-cycle pathway [35] and [36], and SHE cells also contain a normal p53 protein [37] and [38]. The absence of cell transformation and genotoxic effects with DE silica in SHE cells could be explain by effective repair mechanisms of these cells, involving the p53 gene.

As expected, chrysotile asbestos induced micronucleus formation and cell transformation in our experiments. The micronucleus results in SHE and V79 cells were in agreement with those previously published on human mesothelial, SHE or V79 cells [39], [40] and [41]. In the present study, the chrysotile was able to induce significant DNA damage in SHE cells, but comet assays performed with the Fpg showed that this damage was not of the oxidative type. DNA damage induced by asbestos seemed to be strongly dependent on the cell type used, as it was previously demonstrated by Burmeister et al. [42], who reported DNA damage in HMC cells but not in MeT-5A with $3 \mu \mathrm{g} / \mathrm{cm}^{2}$ of chrysotile. In the same work, the authors were unable to detect any Fpg sensitive sites regardless of the cellular type, thus corroborating our findings. A genotoxic effect from chrysotile has also been previously observed in RPMC cells (Rat pleural mesothelial cells) from 0.5 to $10 \mu \mathrm{g} / \mathrm{cm}^{2}$ [43]. Our results with those published before, suggest that these fibres could probably interfere with mitotic spindle and induce a cell cycle arrest as it was shown by Cortez and Machado-Santelli [44].

Taken together, these results highlight the interest to implement, in a chemical hazard assessment, a cell transformation assay, such as that carried on SHE cells. The in vitro genotoxicity assay, as comet or micronucleus assays, can reveal genotoxic effects in a simple way. Gene mutation assays also provide information about the effects of chemicals and mechanisms that may be involved. But some substances, by their mode of action, may not meet these tests in vitro. This difficulty can be avoided by using an in vitro carcinogenicity 
assay, as CTA SHE alternative to long and costly animal testing. The screening of molecules could be improved as well.

\section{5 - CONCLUSION}

In conclusion, amorphous silica DE was able to generate both DNA strand breaks and micronuclei but it did not induce cell transformation, whereas crystalline silica induced cell transformation but without genotoxic effect; and chrysotile induced both micronuclei and cell transformation. Taking into account all these results, the mechanisms involved in the carcinogenicity of silica materials and asbestos are probably different.

In this study we have shown that if comet and micronucleus assays are useful tools for evaluating genotoxic potential of fibres and particles, they do not allow us to predict the transforming potential of silica materials and their carcinogenic potential.

To our knowledge, this is the first time that different forms of micrometric natural silica have been compared for their transforming and genotoxic potential. Further studies will be required to explore the mechanisms involved in the induction of the in vitro carcinogenic effects of these samples.

In the meantime, our results point out that the in vitro genotoxicity assays currently used for hazard assessment cannot alone predict the carcinogenic potential of every substance, as our study has shown for silica materials, and they could be advantageously completed by a cell transformation assay. 


\section{ACKNOWLEDGMENTS}

The authors are grateful to Mrs C. Eypert-Blaison, INRS, for the SEM analyses; Mr. D. Rousset, INRS, for ICP-MS analyses; Mr. T. Lecaque, INRS, for X-ray diffractometry analyses.

This work was funded by INRS. 


\section{REFERENCES}

[1] International Agency for Research on Cancer, Silica, Some Silicates, Coal Dust and paraAramid Fibrils, IARC Monographs on the Evaluation of Carcinogenic Risks to Humans, IARC Press, Lyon, 1997.

[2] B. Fubini, I. Fenoglio, Z. Elias, O. Poirot, Variability of biological responses to silicas: effect of origin, crystallinity, and state of surface on generation of reactive oxygen species and morphological transformation of mammalian cells, J Environ Pathol Toxicol Oncol, 20 Suppl 1 (2001) 95-108.

[3] B. Fubini, A. Hubbard, Reactive oxygen species (ROS) and reactive nitrogen species (RNS) generation by silica in inflammation and fibrosis, Free Radic Biol Med, 34 (2003) 1507-1516.

[4] X. Shi, V. Castranova, B. Halliwell, V. Vallyathan, Reactive oxygen species and silicainduced carcinogenesis, J Toxicol Environ Health B Crit Rev, 1 (1998) 181-197.

[5] B.Z. Zhong, W.Z. Whong, T.M. Ong, Detection of mineral-dust-induced DNA damage in two mammalian cell lines using the alkaline single cell gel/comet assay, Mutat Res, 393 (1997) 181-187.

[6] B.Z. Zhong, T. Ong, W.Z. Whong, Studies on the relationship between treatment condition and micronucleus induction in V79 cells exposed to silica and glass fibers, Mutation research, 391 (1997) 111-116.

[7] Z. Elias, O. Poirot, M.C. Daniere, F. Terzetti, A.M. Marande, S. Dzwigaj, H. Pezerat, I. Fenoglio, B. Fubini, Cytotoxic and transforming effects of silica particles with different surface properties in Syrian hamster embryo (SHE) cells, Toxicol In Vitro, 14 (2000) 409422.

[8] Z. Msiska, M. Pacurari, A. Mishra, S.S. Leonard, V. Castranova, V. Vallyathan, DNA double-strand breaks by asbestos, silica, and titanium dioxide: possible biomarker of carcinogenic potential?, Am J Respir Cell Mol Biol, 43 (2010) 210-219.

[9] E.G. Barrett, C. Johnston, G. Oberdorster, J.N. Finkelstein, Antioxidant treatment attenuates cytokine and chemokine levels in murine macrophages following silica exposure, Toxicol Appl Pharmacol, 158 (1999) 211-220.

[10] R. Nagalakshmi, J. Nath, T. Ong, W.Z. Whong, Silica-induced micronuclei and chromosomal aberrations in Chinese hamster lung (V79) and human lung (Hel 299) cells, Mutation research, 335 (1995) 27-33.

[11] OECD, Detailed review paper on Cell transformation assays for detection of chemical carcinogens., OECD Environment, Health and Safety Publications, No. 31 (2007) ENV/JM/MONO(2007)2018.

[12] R. Benigni, C. Bossa, O. Tcheremenskaia, C.L. Battistelli, A. Giuliani, The Syrian hamster embryo cells transformation assay identifies efficiently nongenotoxic carcinogens, and can contribute to alternative, integrated testing strategies, Mutation research. Genetic toxicology and environmental mutagenesis, 779 (2015) 35-38.

[13] C. Darne, F. Terzetti, C. Coulais, J. Fournier, Y. Guichard, L. Gate, S. Binet, In vitro cytotoxicity and transforming potential of industrial carbon dust (fibers and particles) in syrian hamster embryo (SHE) cells, Ann Occup Hyg, 54 (2010) 532-544.

[14] Z. Elias, O. Poirot, H. Pezerat, H. Suquet, O. Schneider, M.C. Daniere, F. Terzetti, F. Baruthio, M. Fournier, C. Cavelier, Cytotoxic and neoplastic transforming effects of industrial hexavalent chromium pigments in Syrian hamster embryo cells, Carcinogenesis, 10 (1989) 2043-2052.

[15] M.A. Maire, C. Rast, P. Vasseur, Photo catalogue for the classification of cell colonies in the Syrian hamster embryo (SHE) cell transformation assay at $\mathrm{pH}$ 7.0, Mutat Res, 744 (2012) 97-110. 
[16] A. Azqueta, L. Arbillaga, A. Lopez de Cerain, A. Collins, Enhancing the sensitivity of the comet assay as a genotoxicity test, by combining it with bacterial repair enzyme FPG, Mutagenesis, (2013).

[17] A.R. Collins, B. Olmedilla, S. Southon, F. Granado, S.J. Duthie, Serum carotenoids and oxidative DNA damage in human lymphocytes, Carcinogenesis, 19 (1998) 2159-2162.

[18] Z. Elias, O. Poirot, I. Fenoglio, M. Ghiazza, M.C. Daniere, F. Terzetti, C. Darne, C.

Coulais, I. Matekovits, B. Fubini, Surface reactivity, cytotoxic, and morphological transforming effects of diatomaceous Earth products in Syrian hamster embryo cells, Toxicol Sci, 91 (2006) 510-520.

[19] Z. Zhang, H.M. Shen, Q.F. Zhang, C.N. Ong, Involvement of oxidative stress in crystalline silica-induced cytotoxicity and genotoxicity in rat alveolar macrophages, Environmental research, 82 (2000) 245-252.

[20] P. Vasseur, C. Lasne, OECD Detailed Review Paper (DRP) number 31 on "Cell Transformation Assays for Detection of Chemical Carcinogens": main results and conclusions, Mutat Res, 744 (2012) 8-11.

[21] T.W. Hesterberg, J.C. Barrett, Dependence of asbestos- and mineral dust-induced transformation of mammalian cells in culture on fiber dimension, Cancer Res, 44 (1984) 2170-2180.

[22] A.O. Williams, A.D. Knapton, E.T. Ifon, U. Saffiotti, Transforming growth factor beta expression and transformation of rat lung epithelial cells by crystalline silica (quartz), Int $\mathrm{J}$ Cancer, 65 (1996) 639-649.

[23] H.-G. Gao, W.-Z. Whong, D. Cutler, W. W.E., T. Ong, Induction of cell transformation and oncogene activation by silica dust in BALB/c-3T3 cells,, Environ. Mol. Mutagenesis, 21 (1993) 21.

[24] U. Saffiotti, N. Ahmed, Neoplastic transformation by quartz in the BALB/3T3/A31-1-1 cell line and the effects of associated minerals, Teratog Carcinog Mutagen, 15 (1995) 339356.

[25] J.G. Lee, M.C. Madden, W. Reed, K. Adler, R. Devlin, The use of the single cell gel electrophoresis assay in detecting DNA single strand breaks in lung cells in vitro, Toxicol Appl Pharmacol, 141 (1996) 195-204.

[26] T. Leroy, P. Van Hummelen, D. Anard, P. Castelain, M. Kirsch-Volders, R. Lauwerys, D. Lison, Evaluation of three methods for the detection of DNA single-strand breaks in human lymphocytes: alkaline elution, nick translation, and single-cell gel electrophoresis, $\mathrm{J}$ Toxicol Environ Health, 47 (1996) 409-422.

[27] D.W. Fairbairn, P.L. Olive, K.L. O'Neill, The comet assay: a comprehensive review, Mutat Res, 339 (1995) 37-59.

[28] P. Fortini, G. Raspaglio, M. Falchi, E. Dogliotti, Analysis of DNA alkylation damage and repair in mammalian cells by the comet assay, Mutagenesis, 11 (1996) 169-175.

[29] C. Alapetite, A. Benoit, E. Moustacchi, A. Sarasin, The comet assay as a repair test for prenatal diagnosis of Xeroderma pigmentosum and trichothiodystrophy, J Invest Dermatol, 108 (1997) 154-159.

[30] H.L. Karlsson, S. Di Bucchianico, A.R. Collins, M. Dusinska, Can the comet assay be used reliably to detect nanoparticle-induced genotoxicity?, Environ Mol Mutagen., 56 (2015) 82-96. doi: 10.1002/em.21933. Epub 22014 Dec 21938.

[31] A.R. Collins, The use of bacterial repair endonucleases in the comet assay, Methods Mol Biol., 691:137-47. (2011) 10.1007/1978-1001-60761-60849-60762_60768.

[32] M. Fenech, The in vitro micronucleus technique, Mutat Res, 455 (2000) 81-95.

[33] S. Negrini, V.G. Gorgoulis, T.D. Halazonetis, Genomic instability-an evolving hallmark of cancer, Nature reviews. Molecular cell biology, 11 (2010) 220-228. 
[34] W. Chaung, L.J. Mi, R.J. Boorstein, The p53 status of Chinese hamster V79 cells frequently used for studies on DNA damage and DNA repair, Nucleic Acids Res, 25 (1997) 992-994.

[35] E. Huberman, S. Salzberg, L. Sachs, The in vitro induction of an increase in cell multiplication and cellular life span by the water-soluble carcinogen dimethylnitrosamine, Proc Natl Acad Sci U S A, 59 (1968) 77-82.

[36] R.J. Isfort, G.A. Kerckaert, R.A. LeBoeuf, Comparison of the standard and reduced pH Syrian hamster embryo (SHE) cell in vitro transformation assays in predicting the carcinogenic potential of chemicals, Mutat Res, 356 (1996) 11-63.

[37] S. Alexandre, C. Rast, G. Nguyen-Ba, P. Vasseur, Detection of apoptosis induced by topoisomerase inhibitors and serum deprivation in syrian hamster embryo cells, Exp Cell Res, 255 (2000) 30-39.

[38] K.V. Rao, D.M. Mahudawala, A.A. Redkar, Malachite green induced malignant transformation of Syrian hamster embryo (SHE) cells in primary culture: transformation is associated with enhanced expression of altered p53, bcl-2 and decreased sensitivity to apoptosis, Journal of experimental \& clinical cancer research : CR, 19 (2000) 89-98.

[39] I. Poser, Q. Rahman, M. Lohani, S. Yadav, H.H. Becker, D.G. Weiss, D. Schiffmann, E. Dopp, Modulation of genotoxic effects in asbestos-exposed primary human mesothelial cells by radical scavengers, metal chelators and a glutathione precursor, Mutat Res, 559 (2004) 1927.

[40] M.J. Keane, J.W. Stephens, B.Z. Zhong, W.E. Miller, T.M. Ong, W.E. Wallace, A study of the effect of chrysotile fiber surface composition on genotoxicity in vitro, Journal of toxicology and environmental health. Part A, 57 (1999) 529-541.

[41] E. Dopp, J. Saedler, H. Stopper, D.G. Weiss, D. Schiffmann, Mitotic disturbances and micronucleus induction in Syrian hamster embryo fibroblast cells caused by asbestos fibers, Environ Health Perspect, 103 (1995) 268-271.

[42] B. Burmeister, T. Schwerdtle, I. Poser, E. Hoffmann, A. Hartwig, W.U. Muller, A.W. Rettenmeier, N.H. Seemayer, E. Dopp, Effects of asbestos on initiation of DNA damage, induction of DNA-strand breaks, P53-expression and apoptosis in primary, SV40-transformed and malignant human mesothelial cells, Mutat Res, 558 (2004) 81-92.

[43] V. Levresse, A. Renier, F. Levy, V.C. Broaddus, M. Jaurand, DNA breakage in asbestostreated normal and transformed (TSV40) rat pleural mesothelial cells, Mutagenesis, 15 (2000) 239-244.

[44] B.A. Cortez, G.M. Machado-Santelli, Chrysotile effects on human lung cell carcinoma in culture: 3-D reconstruction and DNA quantification by image analysis, BMC cancer, 8 (2008) 181. 


\section{Figure 1. SHE cell proliferation}

Percentage of (A) SHE or (B) V79 cells ( \pm SD) after 24 h of treatment with chrysotile or silica DE, Chd and Min-U-Sil. Sample concentrations are expressed as $\mu \mathrm{g}$ per $\mathrm{cm}^{2}$ of cell culture surface. *: statistically significant $(p<0.05)$ decrease in cell number compared to control.

\section{Figure 2. Micronucleated SHE cells}

Percentage of micronucleated (A) SHE and (B) V79 cells ( \pm SD) after 24 h of treatment with chrysotile, crocidolite or silica DE, Chd, and Min-U-Sil. Sample concentrations are expressed as $\mu$ g per $\mathrm{cm}^{2}$ of cell culture surface. *: statistically significant $(p<0.05)$ decrease in cell number compared to control.

Figure 3. Comet assays after $3 \mathrm{~h}$ or $24 \mathrm{~h}$ of treatment in SHE cells Percentage of DNA in tail (mean of the medians \pm SEM) in SHE cells after treatment (A: 3h; B: 24h) with chrysotile or DE, Chd or Min-U-Sil. Sample concentrations are expressed as $\mu \mathrm{g}$ per $\mathrm{cm}^{2}$ of cell culture surface. *: statistically significant $(p<0.05)$ compared to control.

\section{Figure 4. Comet assays after $3 \mathrm{~h}$ or $24 \mathrm{~h}$ of treatment in V79 cells}

Percentage of DNA in tail (mean of the medians \pm SEM) in V79 cells after treatment (A: 3h; B: 24h) with chrysotile or DE, Chd or Min-U-Sil. Sample concentrations are expressed as $\mu \mathrm{g}$ per $\mathrm{cm}^{2}$ of cell culture surface. *: statistically significant $(p<0.05)$ compared to control. 
TABLE 1. Physico - chemical characteristics of the silica samples

\begin{tabular}{|c|c|c|c|}
\hline Sample & Origin & Structure $^{\mathrm{a}}$ & Chemical impurities (\%) ${ }^{\mathrm{b}}$ \\
\hline Diatomaceous earth (DE) & $\begin{array}{l}\text { Natural, precursor of the } \\
\text { commercial dust }\end{array}$ & Amorphous (100\%) & 2.2 Ca; $1.4 \mathrm{Al} ; 1.3 \mathrm{Fe} ; 0.3 \mathrm{Ti} ; 0.2 \mathrm{Mg}$ \\
\hline Commercial (Chd) & Heated DE & $\begin{array}{l}\text { Partially crystallized: } \\
\text { Amorphous (53\%), cristobalite (47\%) }\end{array}$ & $1.9 \mathrm{Fe} ; 1.6 \mathrm{Al} ; 0.8 \mathrm{Ca} ; 0.3 \mathrm{Ti} ; 0.2 \mathrm{Mg}$ \\
\hline Quartz Min-U-Sil 5 & Natural; US Silica co: (Berkeley) & Crystalline: quartz (100\%) & $0.16 \mathrm{Al} ; 0.05 \mathrm{Fe} ; 0.04 \mathrm{Ca} ; 0.01 \mathrm{Mg}$ \\
\hline Sample & Origin & Structure $^{\mathrm{a}}$ & Chemical composition (\%) \\
\hline Chrysotile & Zimbabwe, UICC A & Serpentine asbestos & $26 \mathrm{Mg} ; 20 \mathrm{Si} ; 1.8 \mathrm{Fe}$ \\
\hline
\end{tabular}

${ }^{\mathrm{a}}$ Determined by X-ray diffractometry.

${ }^{b}$ Determined by inductively coupled plasma (ICP) spectrometry. 
TABLE 2.

A) Average particle diameter and size distribution of silica particles in the different samples ${ }^{\text {a }}$

\begin{tabular}{|c|c|c|c|c|c|}
\hline \multirow{2}{*}{ Sample } & \multirow{2}{*}{$\begin{array}{c}\text { Geometric mean } \\
\text { diameter } \mu \mathrm{m}\left(\mathrm{GSD}^{\mathrm{b}}\right)\end{array}$} & \multicolumn{4}{|c|}{ Percentage of number of particles with diameter $(\mu \mathrm{m})$} \\
\hline & & $<5$ & $5-10$ & $10-20$ & $>20$ \\
\hline Diatomaceous earth (DE) & $1.35(1.48)$ & 96.9 & 3.0 & 0.1 & 0 \\
\hline Commercial (Chd) & $4.85(4.55)$ & 68.9 & 21.6 & 7.2 & 2.3 \\
\hline Quartz Min-U-Sil 5 & $1.33(0.85)$ & 99.5 & 0.5 & 0 & 0 \\
\hline
\end{tabular}

B) Diameter and length distribution of asbestos sample ${ }^{a}$

\begin{tabular}{|c|c|c|c|c|}
\hline \multirow{2}{*}{ Sample } & \multicolumn{4}{|c|}{ Percentage of number of fibres with length $(\mu \mathrm{m})$} \\
\hline & $<\mathbf{1}$ & $1-5$ & $5-20$ & $>20$ \\
\hline Chrysotile $(\mathrm{D}<1 \mu \mathrm{m})$ & 54.9 & 41.2 & 3.9 & C \\
\hline
\end{tabular}


TABLE 3. Morphological transformation into SHE cells following 7 days of treatment with references. *: statistically significant $(p<0.05)$ compared to control (culture medium).

\begin{tabular}{|c|c|c|c|c|c|}
\hline Sample & $\begin{array}{c}\text { Dose } \\
\left(\mu \mathrm{g} / \mathrm{cm}^{2}\right)\end{array}$ & $\begin{array}{c}\text { Morphological } \\
\text { transformation } \\
\text { frequency }(\mathrm{TF})(\%)\end{array}$ & $\begin{array}{l}\text { Number of } \\
\text { transformed } \\
\text { colonies }\end{array}$ & $\begin{array}{l}\text { Total number } \\
\text { of colonies }\end{array}$ & $\begin{array}{c}\text { Relative plating } \\
\text { efficiency (RPE) } \\
\text { (\%) }\end{array}$ \\
\hline Control & 0 & 0 & 0 & 3247 & 100 \\
\hline Chrysotile & 0.48 & 0.09 & 1 & 1107 & 83 \\
\hline Chrysotile & 0.95 & $0.26^{*}$ & 3 & 1154 & 58 \\
\hline Chrysotile & 1.91 & $0.28 *$ & 4 & 1454 & 73 \\
\hline Control & 0 & 0.01 & 1 & 11379 & 100 \\
\hline DE & 3.81 & 0.02 & 1 & 5990 & 105 \\
\hline DE & 7.62 & 0.02 & 1 & 5397 & 95 \\
\hline $\mathrm{DE}$ & 15.24 & $0.11^{*}$ & 3 & 2739 & 57 \\
\hline $\mathrm{DE}$ & 30.48 & 0 & 0 & 811 & 38 \\
\hline Chd & 3.81 & $0.16^{*}$ & 12 & 7398 & 120 \\
\hline Chd & 7.62 & $0.19 *$ & 18 & 9543 & 112 \\
\hline Chd & 15.24 & $0.23^{*}$ & 15 & 6604 & 88 \\
\hline Chd & 30.48 & $0.4^{*}$ & 16 & 4005 & 72 \\
\hline Min-U-Sil & 3.81 & $0.24 *$ & 3 & 1249 & 88 \\
\hline Min-U-Sil & 7.62 & $0.17^{*}$ & 2 & 1197 & 84 \\
\hline Min-U-Sil & 15.24 & $0.71 *$ & 33 & 4678 & 132 \\
\hline Min-U-Sil & 30.48 & $0.77 *$ & 21 & 2738 & 120 \\
\hline
\end{tabular}


Figure 1
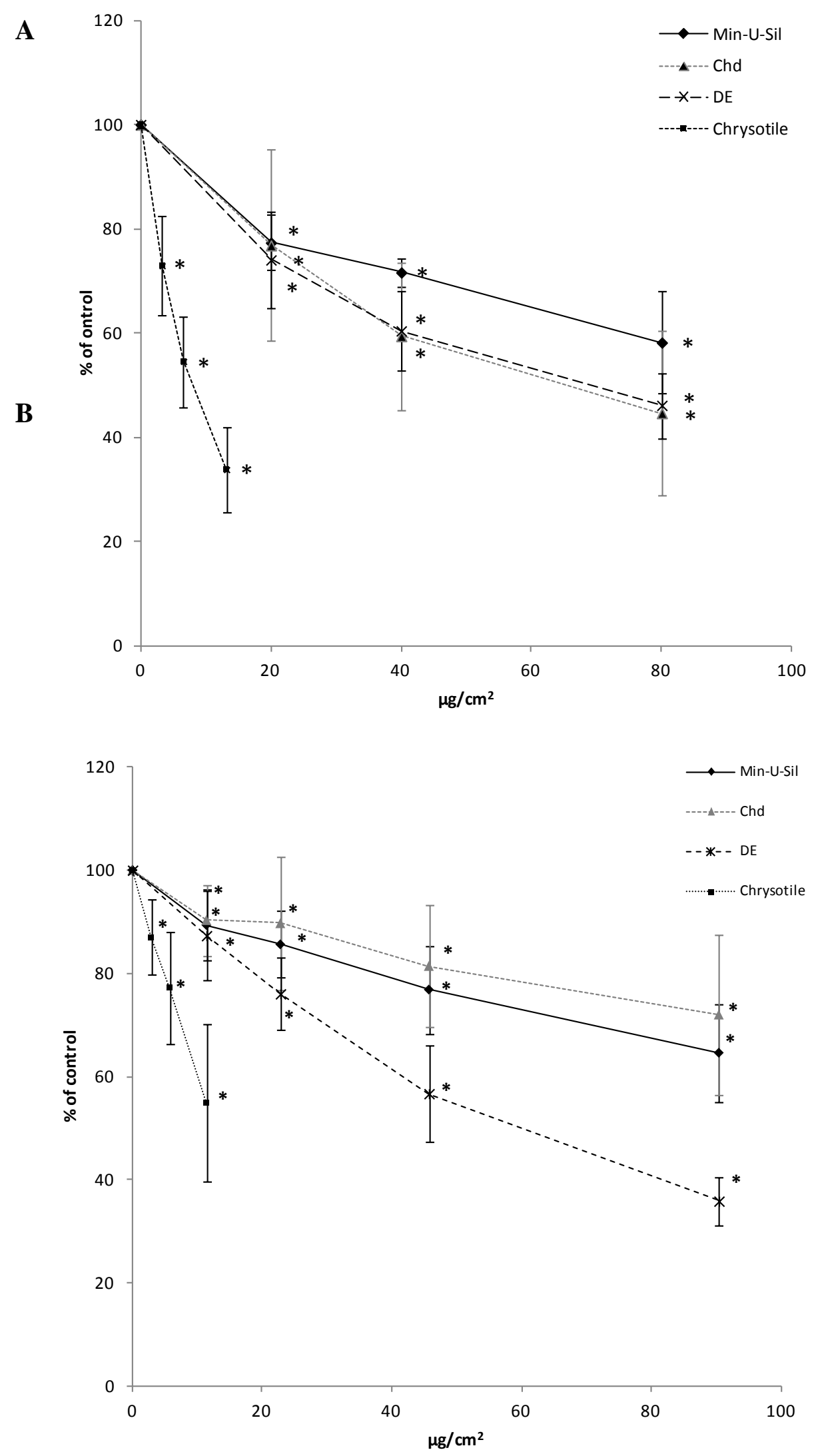
Figure 2

A
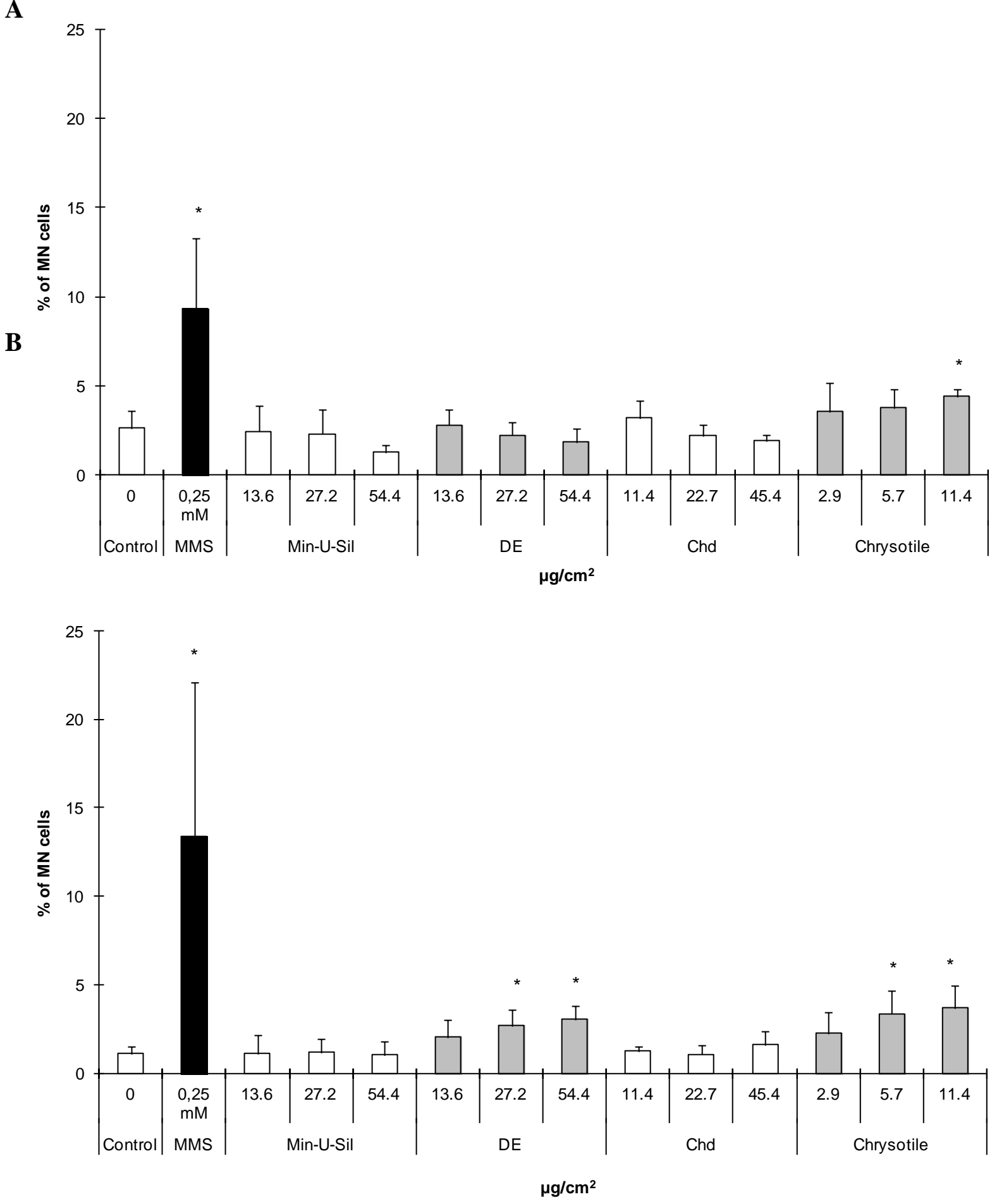
Figure 3

A
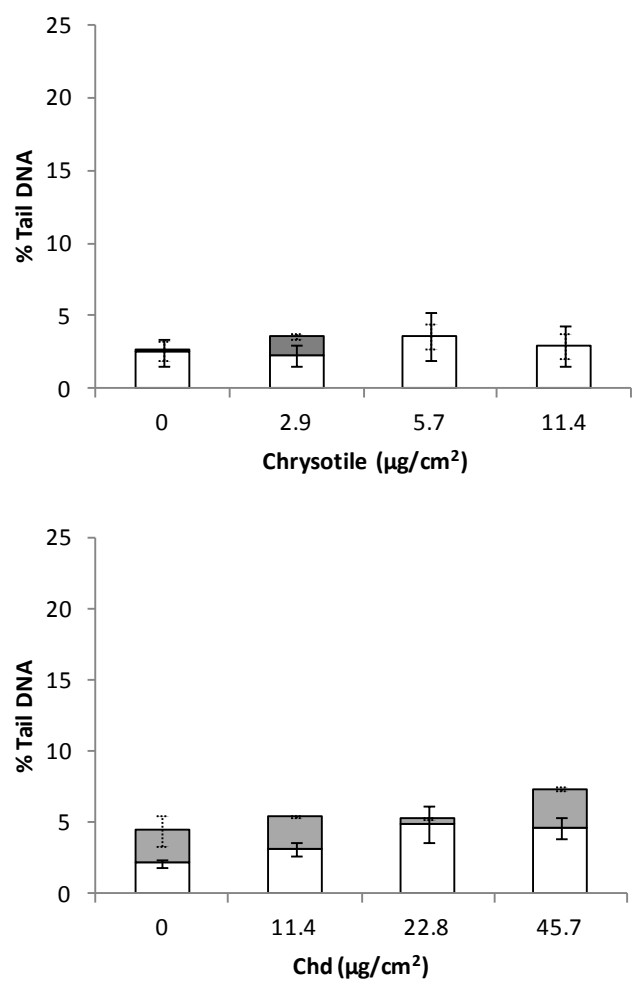

B
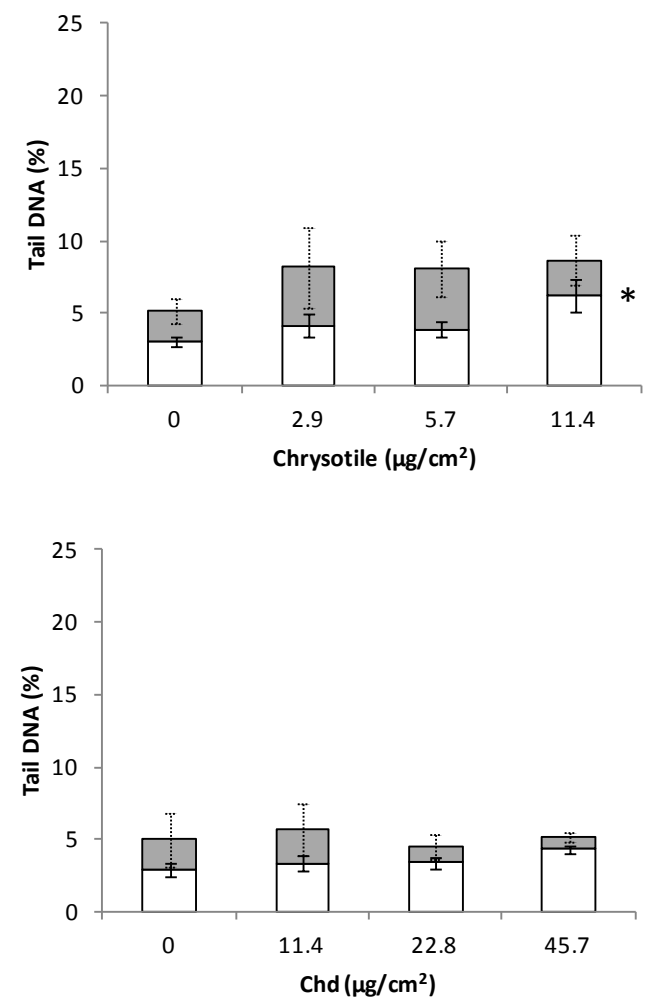
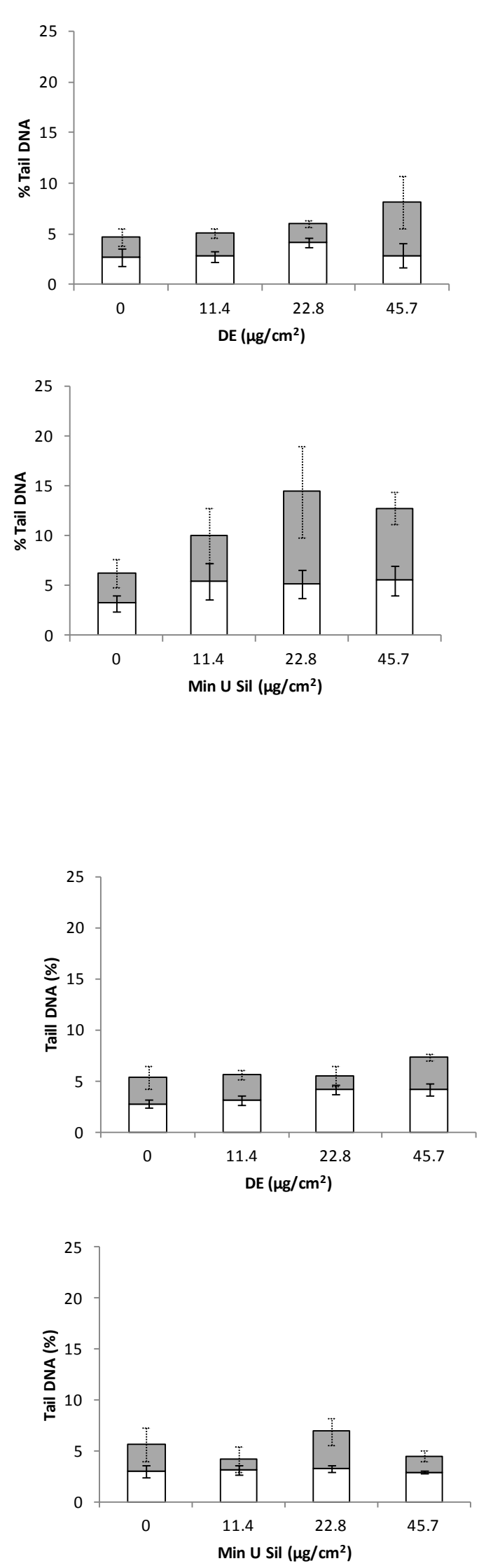
Figure 4

A
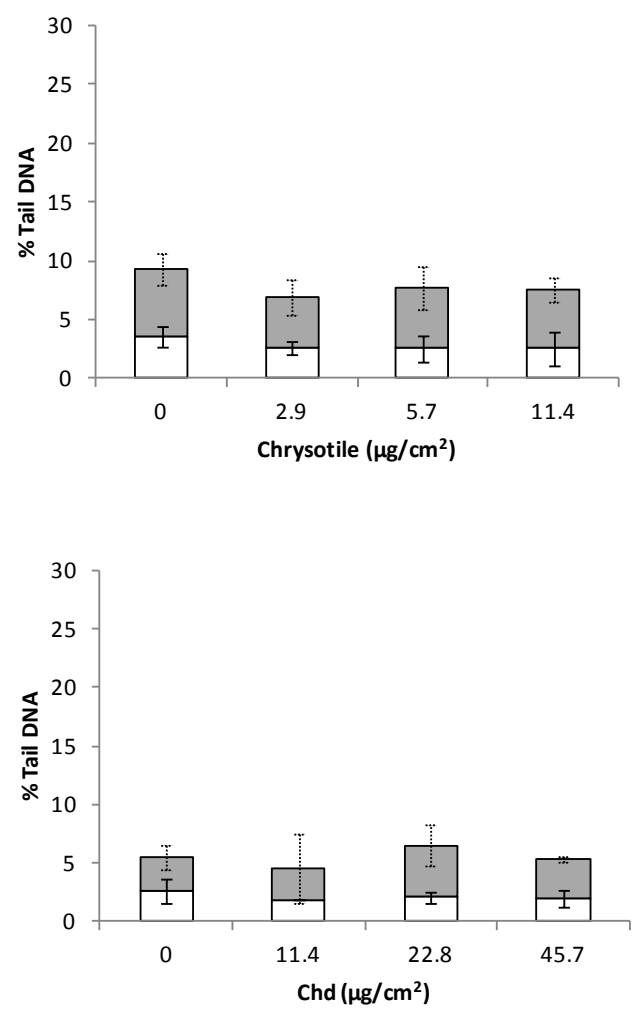

B
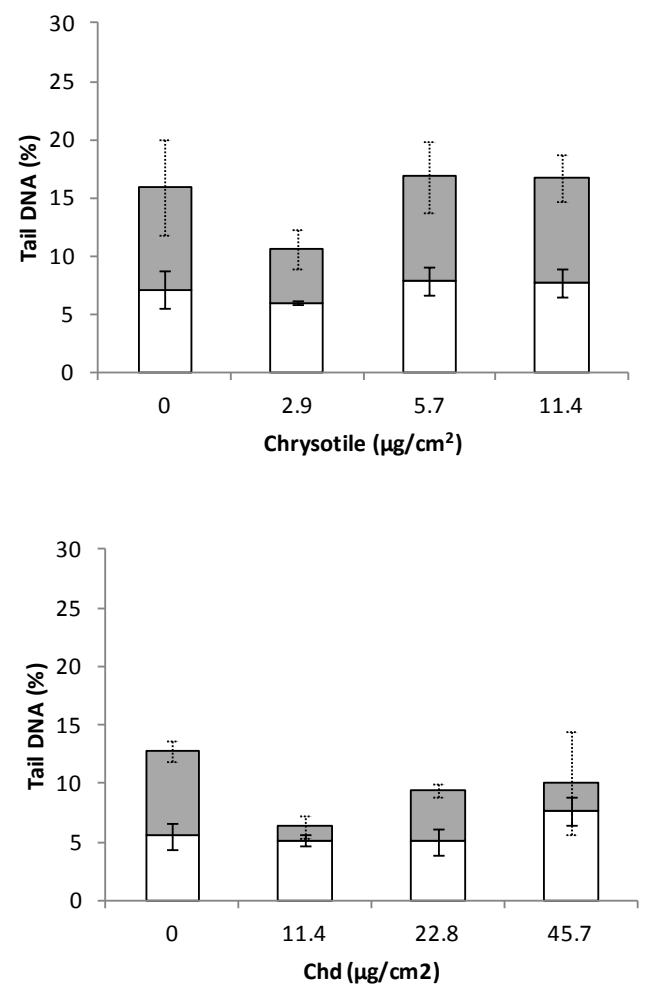
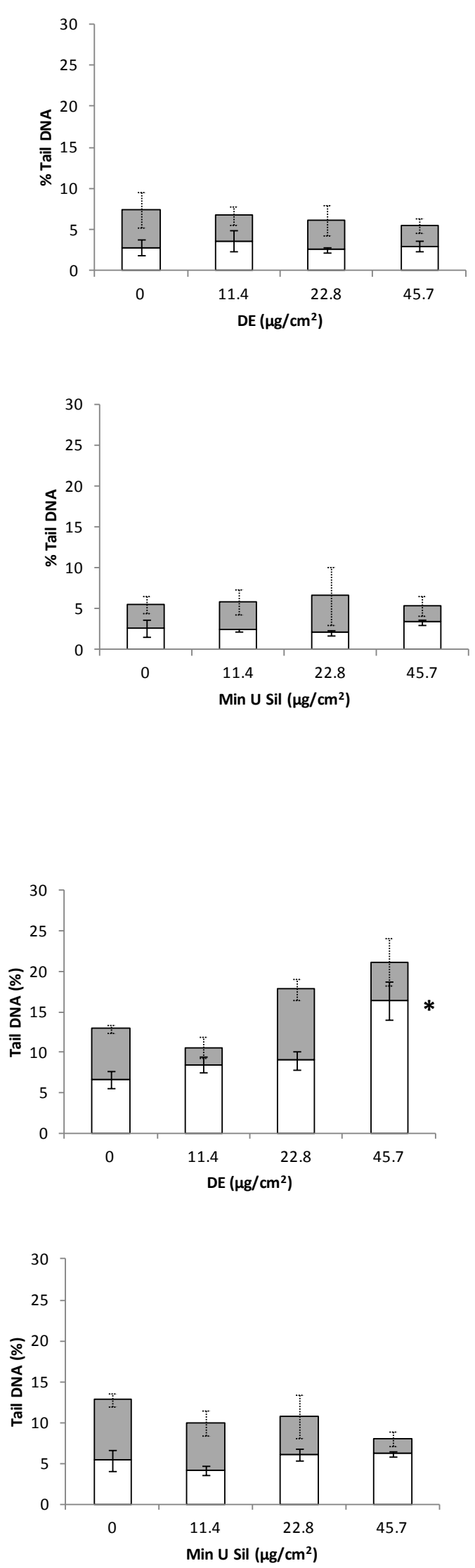